\title{
MENINGKATKAN MUTU PENDIDIKAN MELALUI SUPERVISI PENDIDIKAN UNTUK MENCAPAI KUALITAS PENDIDIKAN NASIONAL
}

\author{
Sofia nourilmanisa \\ Email: sofiailmanisa@gmail.com
}

\begin{abstract}
abstrak
Penulisan artikel ini bertujuan untuk mengetahui situasi dimana pendidikan di indonesia masih tertinggal dan masih ada aspek-aspek yang belum dijalankan dengan semestinya sehingga pendidikan kita menjadi terhambat perkembangannya dengan ada nya beberapa faktor yang menyebabkan keterlambatan itu dan juga ada beberapa solusi untuk meningkatkan kemajuan perkembangan pendidikan indonesia sehingga tercapai pendidikan yang berkualitas dan maju.
\end{abstract}

Kata kunci : Pendidikan indonesia,faktor penghambat pendidikan, solusi kemajuan pendidikan di indonesia

\section{Latar Belakang}

Kualitas pendidikan di indonesia masih tergolong rendah karna masih memiliki masalah-masalah yang serius dari fasilitas sampai pengelolaan keuangan yang masih kacau.di negara lain pendidikan sudah mendukung teknologi dalam artian menggunakan teknologi sebagai sarana dalam pembelajaran bagi siswa serta manajemen sekolah yang baik,maka dari itu pemerintah harus membenah masalah serius ini dan meningkatkan mutu pendidikan yang lebih baik bagi generasi yang akan datang.

Penulis telah menuyusun beberapa masalah yang akan dibahas dalam makalah ini sebagai batasan dalam pembahasan bab isi. Beberapa masalah tersebut antara lain: (1) bagaimana cara meningkatkan mutu pendidikan di Indonesia? (2) apa hal yang pertama harus dilakukan dalam meningkatkan mutu pendidikan? (3) siapa saja yang ikut terlibat dalam meningkatkan mutu pendidikan? Berdasarkan rumusan masalah diatas maka tujuan dalam penulisan makalah ini sebagai beikut : (1) Pembaca bisa mengatahui cara meningkatkan mutu pendidikan(2) pembaca bisa mengetahui hal pertama yang dilakukan untuk meningkatkan mutu pendidikan (3) pembaca bisa mengetahui siapa saja yang ikut terlibat dalam meningkatkan mutu pendidikan 


\section{Pembahasan}

Ada factor-faktor yang menyebabkan mutu pendidikan kita menjadi terhambat yaitu :

1.Kurangnya sarana atau tidak terpenuhi fasilitas penunjang

Banyak sekolah yang belum miliki laboratorium,perpustakan sendiri,gedung sendiri,buku yang kurang dan pemakaian teknologi yang minim dalam pembelajaran.

\section{Kualitas Guru}

Masih ada guru yang belum melaksanakan pembelajaran sesuai yang diminta oleh kementeterian untuk meningkatkan mutu pendidikan dalam artian tidak profesional seperti melaksanakan pembimbingan,penilaian atau evaluasi,merancang metode pembelajaran serta ikut partisipasi dalam membangun generasi muda cerdas.

3.Pendidikan belum merata di seluruh Indonesia

Maksudnya masih ada yang belum memiliki sekolah didaerah terpencil atau pedalaman sehingga menimbulkan masalah buta huruf.

\section{Pendidikan yang mahal}

Terdapat banyak sekolah yang bagus memiliki fasilitas lengkap dan berstandar internasional masih memberlakukan system biaya yang terbilang mahal sehingga membuat masyarakat rendah tidak bisa mengikuti pendidkan yang semestinya.

5.Manajemen dalam kepemimpinan

Masih ada Kepala sekolah yang tidak tau cara mengelolah sekolah yang baik dan benar sehingga menimbulkan masalah seperti buku yang kurang,sarana dan prasarana yang terkendala bahkan sampai keuangan.

6.adanya oknum dalam keuangan disekolah Terdapat banyak sekolah yang belum tau bagaimana cara mengelola uang yang baik dan aman sehingga banyak dimanfaati oleh oknum yang tidak bertanggung jawab.
- Cara meningkatkan mutu pendidikan :

1.Evaluasi dan Merancang kurikulum baru

Dalam merancang kurikulum diperlukannya aspek-aspek yang harus dipertimbangkan seperti pemilihan metode yang cocok dalam pembelajaran,merubah sistim pengelolaan kelas untuk guru dan cara motivasi siswa dalam meningkatkan minat belajarnya. dari semua itu harus dipikirkan dengan matang karna dalam kurikulum terdapat kelebihannya dan kekurangannya.

\section{Meningkatkan Mutu Guru}

Pemerintah seharusanya memiliki program seleksi yang ketat dan sesuai apa yang diminta sehingga guru siap dan mempunyai skill tersendiri karna seleksi dari Pemerintah dan guru memiliki tunjangan yang sesuai kinerjanya disekolah.

\section{Bantuan dana dari Pemerintah untuk} sekolah

Dana yang dikasih oleh pemerintah ke sekolah untuk meningkatkan sarana dan prasarana dalam sekolah seperti Pembangunan labor,ruang UKS, Gedung Olahraga,Perpustakaan,Kelas dan sebagaianya serta buku,proyektor,AC,Komputer,Meja dan kursi,Papan tulis,lemari. 
4.Bantuan untuk Murid yang kurang mampu

Pemerintah Menyediakan dana khusus untuk murid yang kurang mampu dalam keinginan untuk bersekolah supaya setara dengan anak yang lainya, dari semua biaya kebutuhan disekolah pemerintah yang tanggung termasuk duit saku.

5.Pemberantasan korupsi secara besarbesaran dalam sekolah dan lembaga pusat

Pemerintah harus bekerjasama dengan pihak KPK dan Kepolisian dengan komitmen yang jelas dan transparan dalam memberantas korupsi sampai ke akarnya dalam meningkatkan mutu pendidikan sehingga tidak ada lagi penggelapan dana oleh pihak sekolah atau dari atasanya untuk memperkaya diri sendiri dan menyusahkan masyarakat yang ikut dalam pendidikan.

6.kepelatihan

Sebagaimana dikemukakan oleh Sabandi (Sabandi, 2013) Pendekatan peningkatan kualitas pembelajaran yang lebih efektif dapat dilakukan melalui peningkatan kompetensi guru yang dilakukan dengan pelatihan. Pelatihan Armstrong (2006; 137138) merupakan belajar yang dilaksanakan dengan tujuan utama membantu anggota organisasi memperoleh dan mengingat kembali pengetahuan, keterampilan, dan kemampuan dan sikap yang dibutuhkan oleh organisasi.

\section{Kesimpulan}

Berdasarkan pembahasan di atas dapat kita simpulkan bahwa dalam meningkatkan mutu

pendidikan terdapat factor-faktor yang penghambat nya dari kurangnya sarankualitas

guru,pendidikan belum merata,biaya skeolah yang mahal,dan yang lainnya.ada pula cara meningkatkan mutu pendidikan kita yaitu dengan evaluasi dan merancang kurikulum,meningkatkan mutu guru,bantuan dana untuk sekolah dah murid dan pemberantasan korupsi.

\section{Saran}

Penulis masih jauh dari kata sempurna dalam menyelesaikan makalah ini terdapat banyak

yang kekurangan dari segi isi atau penggunanaan kalimat maka dari itu

penulis bisa lebih baik dari ini dan sebagai pembelajaran buat penulis dan diharapkan

memberi kritik dan saranya bagi pembaca.

\section{Referensi}

Sabandi, A. (2013).Supervisi pendidikan Untuk Pengembangan Profesionalitas Guru

Berkelanjutan. Pedagogi, jurnal ilmu

pendidikan,XIII(2), 1-9, Retrived from

http://ejournal.unp.ac.id/index.php/pedagogi/arti cle/view/4275 
https://sahabatkeluarga.kemdikbud.go.id/forum/ showthread.php?tid=18430

http://kabar-

pendidikan.blogspot.com/2011/10/makalah-

kendala-dan-solusi-peningkatan.html 